\section{Dr. Szekanecz, et al, reply}

To the Editor:

We read the letter of Dr. Gonzalez-Gay and colleagues ${ }^{1}$ with great interest; we are happy that they refer to our recent work ${ }^{2}-$ most of their data on atherosclerosis in ankylosing spondylitis (AS) are in agreement with ours. Coming to such agreement is extremely important as there have been controversies regarding vascular involvement in AS. While some groups had reported no changes in carotid atherosclerosis (by common carotid intimamedia thickness; ccIMT) in AS, investigations by Gonzalez-Gay ${ }^{3}$, by Peters, et $a l^{4}$, and by ourselves indeed found increased ccIMT in patients with AS compared to controls, indicating early, subclinical atherosclerosis associated with AS. These data support that carotid ultrasonography is a valuable technique for detection of early, sublinical vascular disease.

ZOLTÁN SZEKANECZ, MD, PhD; NÓRA BODNÁR, MD; SÁNDOR SZÁNTÓ, MD, PhD, Department of Rheumatology; GYÖRGY KEREKES, MD; PÁL SOLTÉSZ, MD, PhD, Angiology and Intensive Care Unit, Third Department of Medicine, University of Debrecen Medical and Health Sciences Center, Debrecen, Hungary. Address correspondence to Dr. Szekanecz; E-mail: szekanecz.zoltan@med.unideb.hu

\section{REFERENCES}

1. Gonzalez-Gay, MA, Gonzalez-Juanatey C, Llorca J. Subclinical atherosclerosis in ankylosing spondylitis [letter]. J Rheumatol 2011;38:2073.

2. Bodnár N, Kerekes G, Seres I, Paragh G, Kappelmayer J, Nemethne ZG, et al. Assessment of subclinical vascular disease associated with ankylosing spondylitis. J Rheumatol 2011; 38:723-9.

3. Gonzalez-Juanatey C, Vazquez-Rodriguez TR, Miranda-Filloy JA, Dierssen T, Vaqueiro I, Blanco R, et al. The high prevalence of subclinical atherosclerosis in patients with ankylosing spondylitis without clinically evident cardiovascular disease. Medicine 2009;88:358-65.

4. Peters MJ, van Eijk IC, Smulders YM, Serne E, Dijkmans BA, van der Horst-Bruinsma IE, et al. Signs of accelerated preclinical atherosclerosis in patients with ankylosing spondylitis. J Rheumatol 2010;37:161-6.

J Rheumatol 2011;38:9; doi:10.3899/jrheum.110448 